\title{
Clasmatosis in Sea Star Immune Responses Observed in T.E.M Invertebrate Antibody. Biosynthesis in Anti-Hrp Responses And In Anti-Alkaline Phosphatase Responses
}

\author{
Michel Leclerc
}

\section{ABSTRACT}

Anti-HRP (Horse-radish peroxydase) and Anti-Alkalin phosphatase immunocytochemical responses occur in Asterina gibbosa (Asterid Echinodermata) after immunizations to HRP and, on the other hand to Alkalin phosphatase enzymes. Classical TEM observations from ergastoplasmic labelling to Golgi apparatus one were done : they shown also "clasmatosis phenomenon" and recall , in a general way invertebrate antibody biosynthesis.

Keywords: Invertebrates, antibody, HRP, Alkalin phosphatase, clasmatosis.

Published Online: July 16, 2020

ISSN: $2684-5199$

DOI :10.24018/ejbio.2020.1.4.61

Michel Leclerc *

Immunology of Invertebrates, France. (e-mail: mleclerc45@gmail.com)

*Corresponding Author

\section{INTRODUCTION}

We know since a long time [1] anti-HRP immunocytochemical reactions occur in the sea star Asterina gibbosa (Asterids Echinodermata). More recently we tested another enzyme: the Alkalin phosphatase as antigen, when injected to Asterina gibbosa [2].

From study to studies, we find new aspects of these reactions we are going to approach, by the discovery of TEM clasmatosis phenomenon. On the other hand, we evoke the Invertebrate antibody biosynthesis.

\section{Materials AND Methods}

\section{A. Materials}

Animals: Asterina gibbosa were purchased from the laboratory of Roscoff (France).

Enzymes: HRP, Alkalin phosphatase were Sigma Products.

\section{B. Methods}

Immunizations, immunocytochemical test were already described [1], [2].

TEM preparation was a classical one which includes an embedding in Epon

Cuts were done with a LKB ultrotome. Observations were realized with a Hitachi Microscope.

\section{RESULTS}

Positive labelling to HRP appear clearly in treated animals (to HRP as antigen) (Fig. 1, 56-59) first in the perinuclear space (Ep) (Fig. 1, 56) second in ergastoplasmic network (Ce) (Fig. 1, 57) in the Golgi apparatus (G) at last in Lysosome (Fig, 1, 58). Similar results were obtained with Alkaline phosphatase (Fig. 2).

Furthermore, for the first time, was shown a particular figure which illustrates the "Clasmatosis phenomenon": a black positive precipitate of cytoplasm. It spreads over the right cell (Fig. 1, 59) which is indicated by 2 similar arrows.

\section{DISCUSSION AND CONCLUSION}

The observed Figures are a recalling of the protein Biosynthesis and, in the same time, an aspect of antibody Biosynthesis in the sea star as a model of study. It recalls also the "Emergence" of primitive antibody in Invertebrates [3]

Genomic asserts this emergence [4]: it is correlated to sea star Igkappa gene.

The sea star Igkappa gene is clearly the oldest IgKappa gene of the immune system of animals.

It shows already two Ig sites. The forms of Igkappa genes are all found in vertebrates, they share many details with the sea star, including the presence of Ig sites.

The preservation of the Igkappa gene in immunized and non-immunized sea stars is an excellent opportunity for further experiments.It is important to notice that the Igkappa chain V-III region HAH of Tupaia chinensis is situated (in the assumptions behind the theory of evolution) between the Igkappa chain precursor V-II region (RPMI/133) and Igkappa chain precursor V-IV region/121. 


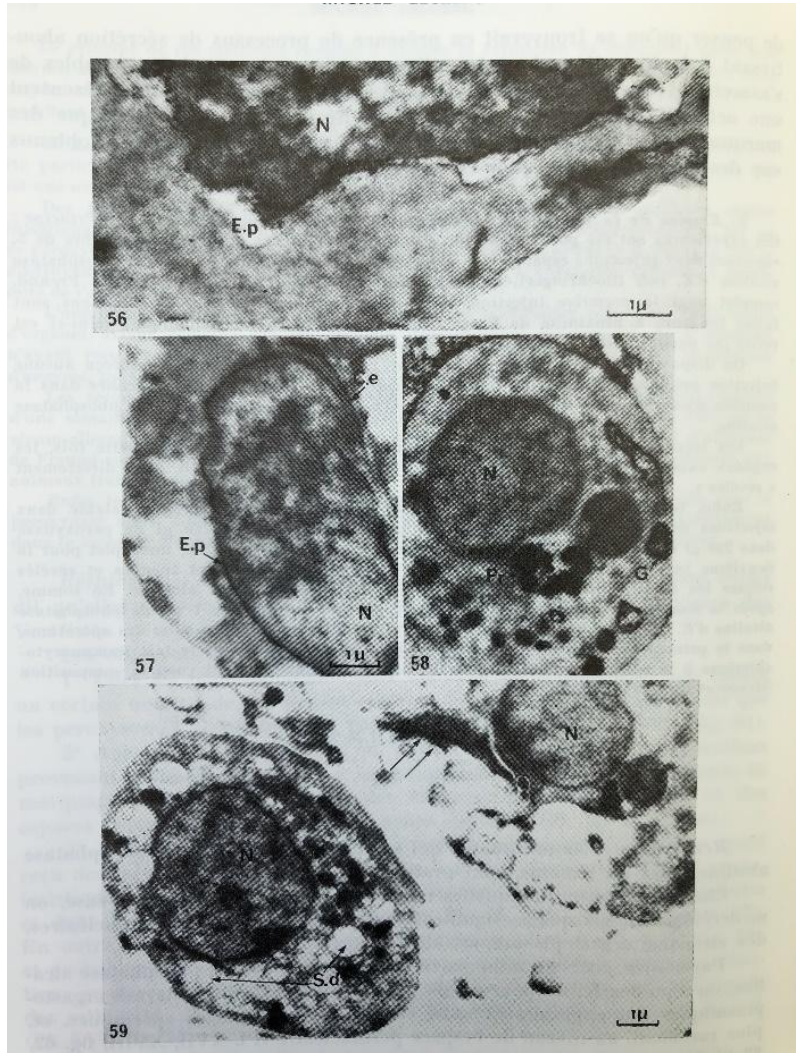

Fig. 1.

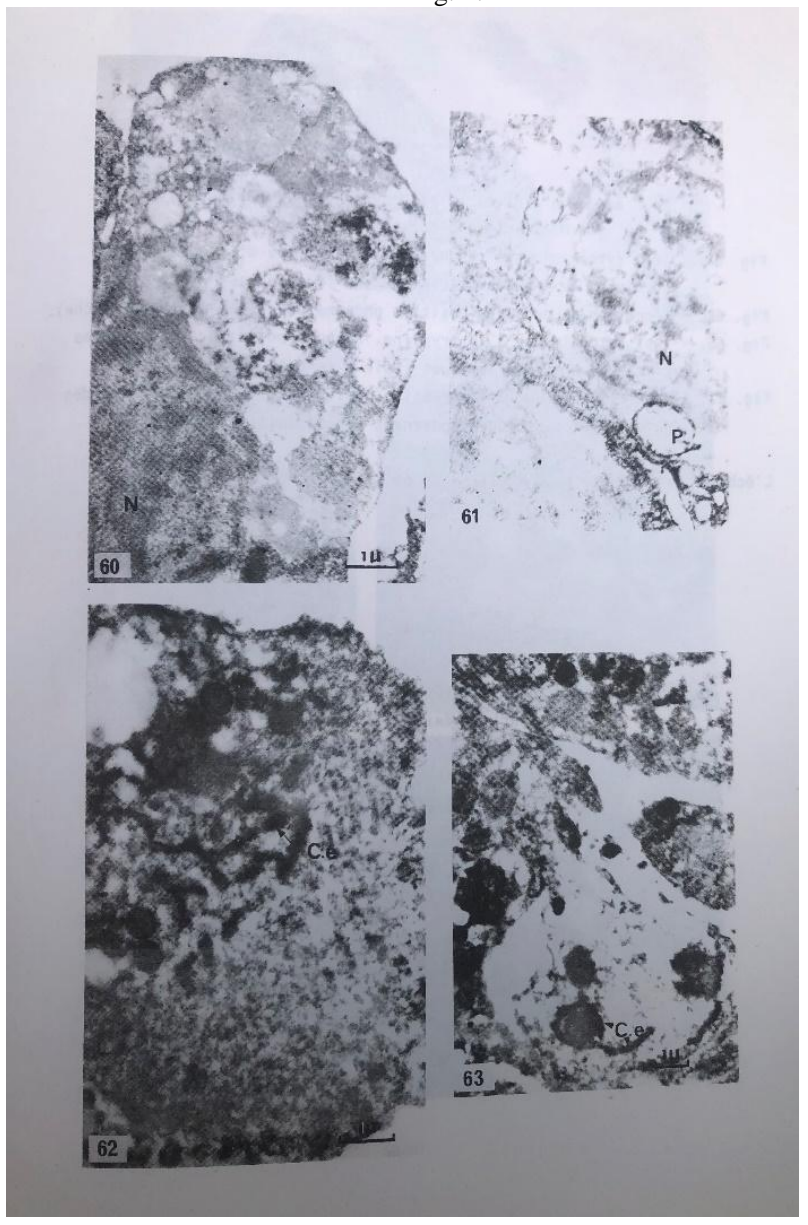

Fig. 2. PLATE II

60-61: controls , injected to HRP and revealed to Alkalin phosphatase. 62-63: sea stars injected to Alkalin phosphatase and revealed to the same antigen. Note the specific labelling at the level of reticulum endoplasmic (Ce)
The preservation of the IgKappa gene for so extended a period of evolution in organisms as distinctively different as sea star, fish, rodent, mammal, indicates that it plays an essential rôle in the survival of the organisms, rôle in the regulation of the immune response.

Additionally, the existence of members of the IgKappa gene family with conserved functional characters, indicate that the sea star IgKappa gene has evolved prior to the evolutionary divergence between Invertebrate and Vertebrates : It must be claimed.

\section{REFERENCES}

[1] Leclerc, M.(1973) Ann.Immun. 124C 363-374.

[2] Leclerc, M. (1974) Thèse de Doctorat ès Sciences, Orléans (France).

[3] Leclerc,M. (2013) Amer. J. Immunol, 94-95.

[4] Vincent, $N$ et al (2014) Meta gene 2, 320-22. 